\title{
Stakeholders' Participatory Framework in Rice Agribusiness
}

\author{
Mustika Sufiati Purwanegara $^{1} *$, Nita Garnida ${ }^{2}$, Nurrani Kusumawati ${ }^{3}$ \\ ${ }^{1,2,3,}$ School of Business and Management, Institut Teknologi Bandung, Indonesia
}

\begin{abstract}
Objective - The purpose of this paper is to investigate the ways rice producers work with other stakeholders to maximize business potential of rice agribusiness by identifying problems, suggesting solutions, and developing a stakeholders' participatory framework as a guideline tool for the implementation.

Methodology/Technique - We conducted a mixed method of qualitative and quantitative research, which was structured in accordance with participatory processes. First, we identified rice agribusiness underlying problem from the supply side through interview to the rice producer and retail observation; and from the demand side by assessing consumer preference through focus group discussion followed by survey to 396 respondents using conjoint analysis. Then, we held stakeholders dialogue involving 56 farmers and 17 cooperative employees.

Findings - This research identified key stakeholders and the way they participate in 3 areas of rice agribusiness, i.e., rice production, skill and knowledge, and marketing strategy to position the authentic characteristics of Pandan Wangi rice from West Java, Indonesia with Geographical Indication certification as signal of quality for its target market.

Novelty - This paper contributes a different approach of stakeholders' participatory framework by focusing on the specific area of participation in rice category.

Type of Paper: Empirical.

JEL Classification: M31, Q13

Keywords: Consumer Preference; Geographical Indication; Participatory Framework; Rice Producer; Stakeholders

Reference to this paper should be made as follows: Purwanegara, M.S; Garnida, N; Kusumawati, N. (2021). Stakeholders' Participatory Framework in Rice Agribusiness, J. Bus. Econ. Review, 5(4) 59-68. https://doi.org/10.35609/jber.2021.5.4(6)
\end{abstract}

\section{Introduction}

Rice is an important food crop in Indonesia; the majority of Indonesia's 267.7 million population consume rice on a daily basis. Among hundreds of rice varieties in Indonesia, Pandan Wangi rice is superior rice cultivated from the Cianjur district, one of the well-known rice-producing areas in West Java province, Indonesia. The Pandan Wangi attributes, i.e., superior quality and Geographical Indication (GI) certification, largely corresponds with previous research relating to rice-eating consumers, which chose special features and quality of rice, certification logo and manufacturing information, and price as their rice preference (Sakolwitayanon et. al., 2018).

\footnotetext{
*Paper Info: Revised: December 24, 2020

Accepted: March 31, 2021

* Corresponding author: Mustika Sufiati Purwanegara

E-mail: mustika@sbm-itb.ac.id

Affiliation: School of Business and Management, Institut Teknologi Bandung, Indonesia
} 
Despite the huge potential market and superior quality, the growth of Pandan Wangi rice agribusiness is still low. This low growth could be attributed to various factors, including limited participation of stakeholders to support rice agribusiness and changes in consumer behavior. Previous research has identified the need for stakeholder analysis to increase the development of the rice agricultural sector. Stakeholder analysis research of agriculture projects in South-East Asia found that farmers, their extension workers, and local authorities are the influential factors (Spangenberg et. al., 2018). However, the way to achieve successful stakeholder analysis remains unclear (Wang \& Aenis, 2019). Current stakeholder analysis guidelines are considered too general, lacking applicability in stakeholder identification and good practice, and need a systematic framework particularly in a complex setting (Fassin, 2008; Jepsen \& Eskerod, 2009; Wang \& Anies, 2019).

Previous research suggests that stakeholders' participatory approach is capable of providing more accurate result based on key stakeholders' opinion in their specific area of expertise (Karakosta et. al., 2017). This approach offers diversity to analysis through participation of multidisciplinary stakeholders at different levels of expertise and background (Pedrosa \& Pereira, 2006). The stakeholders' participatory approach has been used in the context of sustainable development or environmental studies (Pedrosa \& Pereira, 2006; Krywkow \& Hare, 2008; Lagabrielle et. al., 2010; Jarvis, 2015; Karakosta et. al., 2017), regional studies (Slocum, 2003), improving working condition (Laitinen et. al., 1998), and assessing fisheries (Kaiser \& Forsberg, 2001). Despite evidence for the effectiveness of this approach in various studies, little is known about the use of stakeholders' participatory approach in the context of how the stakeholders could participate to increase the growth of rice agribusiness.

In view of the above, there is a need to investigate participation of key stakeholders in rice value chain as an effort to maximize rice agribusiness potential. This paper fills the knowledge gap by investigating the underlying problem of rice agribusiness from the perspective of supply and demand and formulating a method for stakeholders to effectively participate in rice agribusiness. Accordingly, the objective of this study is to develop stakeholder's participatory framework as a guideline to solve rice agribusiness growth problem. In particular, we assess preference of rice eating consumers, which will generate input for the framework development and thus, allow the Pandan Wangi rice agribusiness to achieve the expected outcomes.

\section{Literature Review}

\subsection{Stakeholder analysis}

A stakeholder is 'any individual, group, or institution who has a vested interest in the natural resources of the project area and/or who potentially will be affected by project activities and have something to gain or lose if conditions change or stay the same' (Golder \& Gawler, 2005, p. 1). The stakeholders can have a positive or negative effect depending on their decisions or actions of other individuals, groups or organizations (Freeman, 1984; Grimble, 1998; Bryson et. al., 2011). The extant literature explains the guideline for conducting stakeholder analysis, which in general terms consists of the following steps: identifying issues; identifying stakeholders; mapping the stakeholders based on their interest, influence, importance, and impact; and investigating stakeholders interrelations, engagement, and interaction (e.g. in Grimble \& Chan, 1995; Grimble, 1998; Brugha \& Varvasovzky, 2000; Golder \& Gawler, 2005; Reed et. al., 2009; Indumathi, et. al., 2017; Spangenberg et. al., 2018; Wang \& Aenis, 2019). 


\subsection{Stakeholders' participatory approach in rice agribusiness}

Participatory approach is a useful tool in facilitating a wide range of stakeholder analysis purposes. According to its purpose, stakeholders can participate at different levels, e.g., through a one-way participation, consultation or bi-directional participation, or active participation in partnership (Slocum, 2003). The participatory approach can help to frame the identified problems and future actions based on stakeholders' opinion; and facilitating stakeholders' participation to generate knowledge and enhance policy making (Pedrosa \& Pereira, 2006).

In rice agribusiness, the stakeholders correspond to the value chain of rice production, which comprises different stages including harvesting, procurement, transportation, storage, processing, grading, packing, and delivering rice to end consumer (Indumathi et. al., 2017). These stakeholders include farmers, association of farmers, consumers, government or authorities, raw material suppliers, industry associations, competitors, general public, research institution, and middlemen (Flor et. al., 2019; Spangenberg et. al., 2018; Indumathi et. al., 2017; Alemu \& Shiratori, 2011; Okry et. al., 2010).

A participatory process initially contains of the identification of suitable stakeholders and relevant information (ADB, 2001). The participatory approach needs to gather stakeholders' feedback and opinion, involving them in the decision-making process. In particular, Krywkow and Hare (2008) have developed 4 main phases of participatory processes, which encompasses: first, preparation of problem analysis, stakeholder layer, and draft planning; second, publication or stakeholders' familiarization of problem and planning; third, dialogue among stakeholders to gain more solid information and contribute knowledge; and fourth, gaining response from the participants and validating the results.

\subsection{Preference of rice eating consumers}

There are many factors that drive consumers preference toward a particular product, for instance, features embedded to a product such as material substance of shape, size, taste, color, and consistency; brand elements, such as label, name, packaging, and use instruction; and the status given to the person acquiring and using that product (Voicu, 2008). Previous research states that preference of rice eating consumers related to income and new product exposure (Isvilanonda \& Kongrith, 2008; Suwannaporn et. al., 2008), physical attributes (Senarah \& Samaraweera, 2017), rice quality (Al Hasan et. al., 2008; Isvilanonda \& Kongrith, 2008); price (Anang et. al., 2011; Azabagaoglu \& Gaytancioglu, 2009; Al Hasan et. al., 2008; Isvilanonda \& Kongrith, 2008), and is significantly affected by location, economic class, family size, and educational attainment (Bairagi et. al., 2018; Cuevas et. al., 2016; Ogundele, 2014; Azabagaoglu \& Gaytancioglu, 2009; Al Hasan et. al., 2008).

The view of rice as a uniform commodity is clearly outdated (Lançon et. al., 2003). The popularity of rice is attributed to its characteristics, such as menu versatility, ease of preparation, appealing flavor, and relatively cheap price (Childs, 1993). Customers will respond to the quality level of the grain, which is characterized by rice grain variety and tradition or naturalness (Azabagaoglu \& Gaytancioglu, 2009; Suwannaporn et. al., 2008); cleanliness, softness, whiteness, purities, and shape (Bairagi et. al., 2018; Ogundele, 2014; Anang et. al., 2011; Azabagaoglu \& Gaytancioglu, 2009; Al Hasan et. al., 2008); taste and aroma (Bairagi et. al., 2018; Anang et. al., 2011; Al Hasan et. al., 2008); convenience, ease of cooking, and cooking time (Anang et. al., 2011; Azabagaoglu \& Gaytancioglu, 2009); and origin of rice (Anang et. al., 2011; Al Hasan et. al., 2008). 


\section{Methodology}

This study adapts the participatory process of Krywkow and Hare (2008), structuring the research method into 2 stages described below.

\subsection{Problem identification and familiarization}

We conducted a series of qualitative and quantitative studies to identify the underlying problems of Pandan Wangi rice agribusiness. First, to gain insight from the supply side, we interviewed 3 representatives of Cooperative Sukamulya, the Pandan Wangi rice producer in Cianjur district. We also conducted retail observation at 8 supermarkets in Bandung city, where Pandan Wangi rice is largely marketed and sold.

Second, to gain insight from the demand side, we conducted focus group discussion to 8 rice eating consumers to understand their preference in choosing rice. Then, we conducted survey to confirm the focus group discussion result. We developed survey instrument based on consumers insight from focus group discussion, which is supported by the literature review. We used a purposive sampling method to recruit respondents with the criteria rice eating consumer to cover ABCDE class of socio-economic status (Nielsen, 2010). Then, we were able to collect reply from a total of 396 respondents. The data collected from these researches are useful to familiarize the comprehensive profile of Pandan Wangi rice agribusiness to the stakeholders in the subsequent research.

\subsection{Stakeholders dialogue}

We conducted stakeholder dialogue to gather stakeholders' opinion toward the underlying problem of Pandan Wangi rice agribusiness and to involve them in formulating objectives and participation activities planning. Accordingly, we invited stakeholders who are currently involved in the supply chain of Pandan Wangi rice agribusiness, i.e., 56 farmers and cooperative members, and 17 cooperative board members.

\section{Results}

\subsection{Pandan Wangi rice agribusiness profiling}

Pandan Wangi rice is the variety of rice that is only planted in a particular region in 7 districts of Cianjur, Cilaku, Cibeber, Warungkondang, Gekbrong, Cempaka and Cugenang in West Java, Indonesia. Pandan Wangi rice has tasty, fluffy, and pandan-scented rice characteristics, mainly due to the distinctive soil texture in those areas. In 2016, the Indonesian Directorate General of Intellectual Property Rights awarded Pandan Wangi rice Geographical Indications (GI) intellectual property right certification due to its unique characteristics. Pandan Wangi rice is produced and sold under Cooperative Sukamulya, an Indonesian typical of small medium enterprise that is owned by the farmers. Cooperative Sukamulya acts as the representation of farmers to manage the post-harvesting activities, including packaging, distributing, and selling the finished rice product to reseller agent, supermarket, and end consumers using the brand name Pandan Wangi Menak rice. Retail observation reveals tight competition among rice varieties and brands in the market. There are 59 brands of packaged rice available in the supermarkets of which each of them has up to 11 varieties of rice, i.e. Cianjur, Rojolele, Setra Ramos, Slip, IR64 Setra, Jasmine, Jitai, Long Grain, Long Grain Crystal, Mutiara Medium Grain, and fragrant rice including Pandan Wangi. In particular, there are 22 brands claiming as Pandan Wangi rice but none of them embeds the GI certification in the packaging. According to the retailer, these brands are not originally from Cianjur district. While Pandan Wangi Menak rice sells the product at a premium price of IDR $20,000 / \mathrm{kg}$, the competitor brands of fragrant rice variety have lower price range, i.e., IDR 15,000 up to IDR 17,500 per $\mathrm{kg}$. 


\subsection{Preference of rice eating consumers}

This study used descriptive statistics to describe the respondents' demographic profile. The, majority of respondents are female (93.94\%) at mature age (48.73\% is above 42 years old). Their occupation is varied, but the majority are housewives (34.34\%). The majority of respondents comes from socio-economic status class A (54.3\%) with basic monthly expenditure more than IDR 3 million (Nielsen, 2010). The focus group discussions with rice eating consumers revealed that consumers determine their preference based on rice intrinsic characteristics, such as cleanliness, taste and aroma, color, and shape; and search attributes, such as brand, price, and rice variety. Accordingly, we identified 5 factors, i.e., physical attributes (color and shape), brand familiarity, rice variety, acceptable price range, and rice quality (cleanliness, taste and aroma). Then, we measured consumer preference toward these factors using conjoint statistical analysis. The results generated very good prediction results, i.e., Pearson's R at 0.957 and Kendall's Tau at 0.871 , and both correlation values were significant at $0.000(<0.050)$ (see Table 1). The conjoint analysis results show that physical attributes is the most important factor (33.92). followed by rice quality (23.89), acceptable price range (19.05), rice variety (14.01), and brand familiarity (9.04) as the least important. Conjoint procedures also attempt to assign values to the levels of each attribute. The analysis results show that the majority of consumers prefer clean white and long grain rice (-3.7963) with tasty, flavored, and clean (no lice) rice quality (-2.6893). They tend to buy the familiar brands (-0.6324), prefer to consume Pandan Wangi rice (1.0185), and prefer the price range IDR $9,000-15,000$ per $\mathrm{Kg}(-1.6215)$.

Table 1. Average importance, Utilities, and Estimates part worth values

\begin{tabular}{|c|c|c|c|c|c|c|c|}
\hline Factors & $\begin{array}{c}\text { Average } \\
\text { importance }\end{array}$ & Attributes & Utilities & Dev2 & Std. Dev. & $\begin{array}{c}\text { Estimate } \\
\text { part worth }\end{array}$ & $\begin{array}{c}\text { A range } \\
\text { of part } \\
\text { worth }\end{array}$ \\
\hline \multirow[t]{2}{*}{$\begin{array}{c}\text { Physical } \\
\text { attributes }\end{array}$} & \multirow{2}{*}{33.92} & $\begin{array}{c}\text { Clean white and } \\
\text { long grain }\end{array}$ & -3.7963 & 14.4119 & 3.3437 & 1.8286 & \multirow{2}{*}{3.6572} \\
\hline & & $\begin{array}{l}\text { Yellowish and } \\
\text { round grain }\end{array}$ & 3.7963 & 14.4119 & 3.3437 & 1.8286 & \\
\hline \multirow{2}{*}{$\begin{array}{c}\text { Brand } \\
\text { familiarity }\end{array}$} & \multirow{2}{*}{9.04} & Familiar brand & -0.6324 & 0.3999 & 0.0928 & 0.3046 & \multirow{2}{*}{0.6092} \\
\hline & & Unknown brand & 0.6324 & 0.3999 & 0.0928 & 0.3046 & \\
\hline \multirow[t]{3}{*}{ Rice variety } & \multirow{3}{*}{14.10} & Rojolele & 0.5768 & 0.3327 & 0.0772 & 0.2778 & \multirow{3}{*}{0.9812} \\
\hline & & PandanWangi & -1.0185 & 1.0373 & 0.2407 & 0.4906 & \\
\hline & & Setra Ramos & 0.4417 & 0.1951 & 0.0453 & 0.2128 & \\
\hline \multirow{3}{*}{$\begin{array}{c}\text { Acceptable } \\
\text { price range } \\
\quad(/ \mathbf{K g})\end{array}$} & \multirow{3}{*}{19.05} & $\begin{array}{l}\text { IDR } 9,000- \\
15,000\end{array}$ & -1.6215 & 2.6293 & 0.6100 & 0.7810 & \multirow{3}{*}{1.7873} \\
\hline & & $\begin{array}{l}\text { IDR } 15,000- \\
22,000\end{array}$ & -0.2338 & 0.0547 & 0.0127 & 0.1126 & \\
\hline & & $>$ IDR 22,000 & 1.8553 & 3.4421 & 0.7986 & 0.8937 & \\
\hline \multirow[t]{3}{*}{ Rice quality } & \multirow[b]{2}{*}{23.89} & $\begin{array}{c}\text { Flavorless and } \\
\text { contain lice }\end{array}$ & 2.6839 & 7.2033 & 1.6713 & 1.2928 & \multirow[b]{2}{*}{2.5855} \\
\hline & & $\begin{array}{c}\text { Tasty, flavored } \\
\text { and clean (no } \\
\text { lice) }\end{array}$ & -2.6839 & 7.2033 & 1.6713 & 1.2928 & \\
\hline & & Constant & 13.8691 & & & & \\
\hline arson's R & $=0.957$ & \multicolumn{2}{|c|}{ Significance $=0.0000$} & & & & \\
\hline Kendall's tau & $=0.871$ & Significance $=$ & 0000 & & & & \\
\hline
\end{tabular}


Further analysis generated the best combination of rice product attributes, which equals to the highest total amount of estimate part worth value of attributes level. It was found that the set attributes of familiar brand of Pandan Wangi rice variety that has clean white and long grain physical attributes, and tasty, flavored, and clean (no lice) rice quality; and at the price range IDR 9,000 - 15,000 per $\mathrm{Kg}$ is the most preferable combination attributes of rice product.

\subsection{Stakeholders participatory analysis}

\subsubsection{Problem analysis and objective formulation}

In the stakeholders' dialogue, the participants discussed the underlying problem of Pandan Wangi rice agribusiness. First, while it is struggling to compete with other brands in the same fragrant rice category due to its relatively high price, Pandan Wangi Menak rice has not optimized its strength, the authenticity of Pandan Wangi characteristics proven by GI certification. Further, insights from consumers lead to the opportunities and challenges for Pandan Wangi rice agribusiness. Pandan Wangi is the preferable rice variety that has the quality preferred by consumers, i.e., clean, tasty and flavoured with its Pandan-scented characteristics. However, consumers prefer clean white color and long grain shape instead of yellowish color and round grain shape physical attributes that belong to Pandan Wangi rice.

The participants formulate objectives as an effort to eliminate the problems: first, to increase consumer knowledge on the characteristics in pair with physical attributes of Pandan Wangi rice; second, to position the authenticity of Pandan Wangi rice characteristics proven by GI certification in the consumers' mind; third, to increase brand familiarity; and fourth, to optimize Pandan Wangi rice production.

\subsubsection{Stakeholders identification and participatory area}

In the stakeholders' dialogue, the participants realized and admitted their limitation in knowledge and resources to meet the formulated objectives. Therefore, stakeholders participatory process began with the identification of additional stakeholders that may affect or have a vested interest in the advancement of Pandan Wangi rice agribusiness growth. Accordingly, the participants determined government, agricultural and industry association, supplier of raw material, marketing expert from academic institution, and brand consultant as additional stakeholders that need to involve based on their expertise and vested interest in 3 participatory areas, i.e., rice production, skill and knowledge, and marketing strategy.

\section{Discussion}

Participation of stakeholders in a project or program design and implementation is the key to success and is important to generate a sense of ownership if initiated early in the development process, provides opportunities for stakeholders to learn, build their capacity, and enhance their responsibility (Golder \& Gawler, 2005). Based on a comprehensive examination of the Pandan Wangi rice agribusiness, this study proposes a stakeholders' participatory framework as a guideline tool to solve rice agribusiness growth problems. The framework illustrates the interrelationship of stakeholders through the way they participate in participation areas of rice agribusiness, as presented in Figure 1.

\subsection{Rice production}

The fact that Pandan Wangi rice could not offer competitive prices in the market may stem from the ineffectiveness of rice cultivation; farmers are still currently practicing traditional farming. To eliminate this problem, farmers and their cooperatives need to apply technology-based machineries instead of manual 
farming tools, and to feed the plantation with good quality seed, fertilizer, and pesticide. We suggest additional stakeholders to participate in rice production areas based on their expertise and value (Indumathi et. al., 2017). First, industry associations need to participate by giving information on the efficient machineries in rice farming. Then, the government needs to legitimize the standardized quality of raw material supplied to the farming. Afterward, the suppliers could be directly involved by ensuring the access of raw material delivered to the farmers. The involvement of local seed suppliers will improve smallholder farmers' access to seed supply (Okry et. al., 2010).

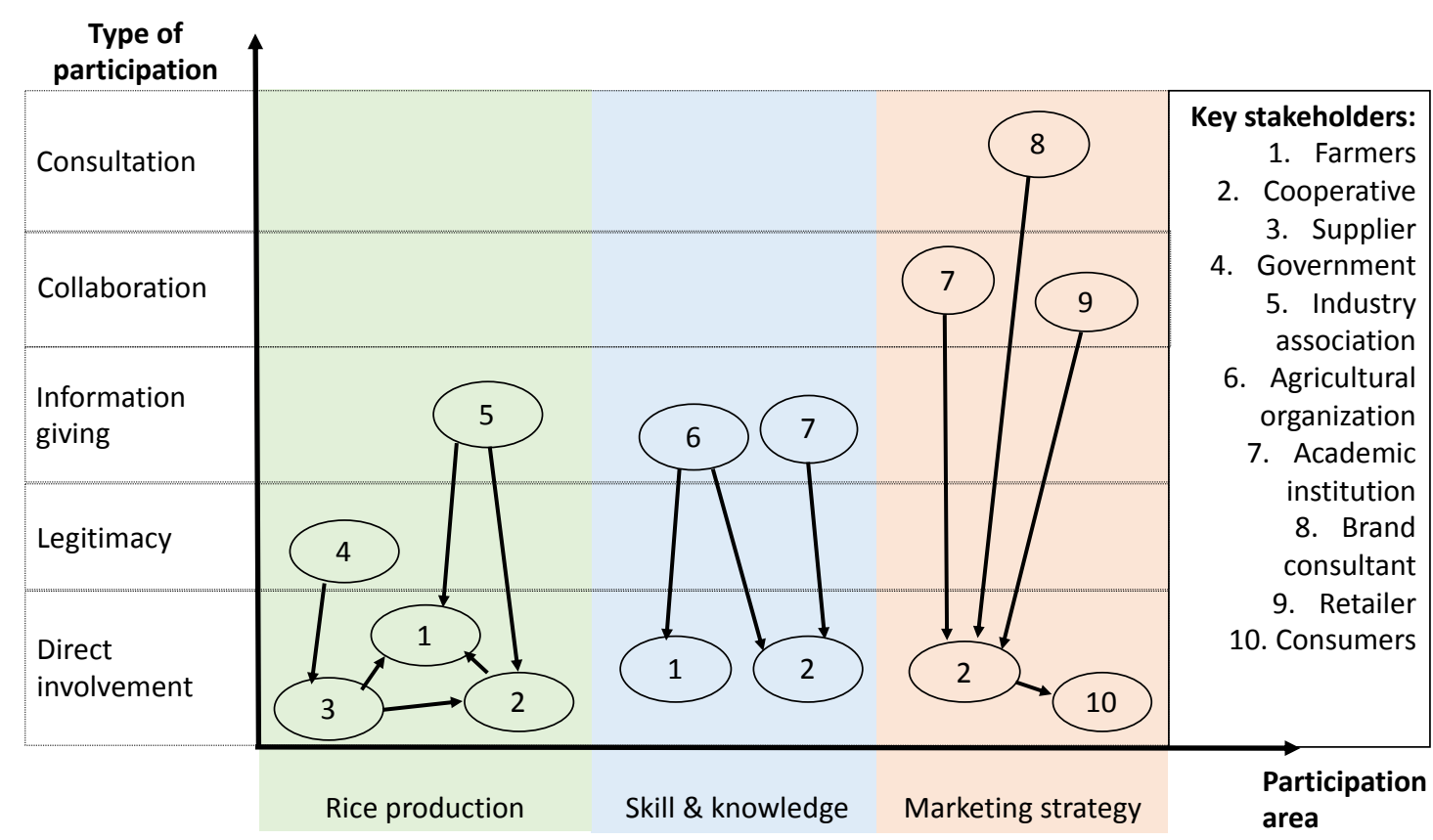

Figure 1. Stakeholders participatory framework of rice agribusiness

\subsection{Skill and knowledge}

Skill and knowledge of farmers and their cooperatives is one of the main issues in increasing the quality and quantity of rice production. Currently the ways farmers plant, cultivate, and harvest the rice are based on tacit knowledge passed down over generations. On the other hand, the cooperatives has limited skill and knowledge to run the day-to-day operations and business practice. Therefore, the agricultural organization, such as Indonesian Farmer Alliances (Aliansi Petani Indonesia or API), Indonesian Farmer Union (Serikat Petani Indonesia or SPI), and academic institution need to participate by holding an information gathering or training on good farming for farmers; and operation and business practice training for the cooperatives. The contribution and legitimacy of public organizations is considered high (Indumathi et. al., 2017) because they are more accepted by the farmers community.

\subsection{Marketing strategy}

Consumer preference to consume Pandan Wangi rice variety and the existence of competitors' brand claiming as Pandan Wangi rice without evidence of GI certification indicate the business growth of Pandan Wangi rice is actually good. However, consumers have low knowledge on the physical attributes of Pandan Wangi rice and its GI certification. As such they could not differentiate Pandan Wangi rice from other fragrant rice varieties. On the other hand, as the owner of GI certification intellectual property right, 
cooperative Sukamulya has limited skills in marketing Pandan Wangi Menak rice brand, as such it loses competition from the non-authentic Pandan Wangi rice brands.

To eliminate this problem, the cooperative needs to accentuate its competitive advantage, i.e. the authenticity of Pandan Wangi rice with tasty, fluffy, and Pandan-scented rice characteristics, originated from Cianjur district, and GI certification as the point of differentiation from the competitors. The GI certification also becomes the signal of quality, which corresponds to premium price of the authentic Pandan Wangi rice. We suggest participation of brand consultants to help the cooperative design marketing communications to educate consumers on the characteristics and physical attributes of Pandan Wangi rice as well as to communicate the positioning of authentic Pandan Wangi Menak rice through logos, slogans, and packaging. Further, the cooperatives need to collaborate with marketing experts from academic institutions to target consumers who are willing to pay premium prices to provide high quality rice to their family. Based on demographic profiles, these consumers belong to households with socio-economic status class A, i.e., basic monthly expenditure more than IDR 3 million (Nielsen, 2010). Lastly, we suggest the cooperatives should collaborate with retailers to increase Pandan Wangi Menak rice brand familiarity through repetitive exposure of its brand positioning at the point of purchase.

\section{Conclusion}

This study has developed a stakeholders' participatory framework by identifying key stakeholders, i.e., farmers, cooperative, supplier, government, industry association, agricultural organization, academic institutions, brand consultants, retailers, and consumers; and suggesting the way stakeholders participate in 3 main participatory areas, i.e., rice production, skill and knowledge, and marketing strategies. Through 5 types of participation, i.e., direct involvement, legitimacy, information giving, collaboration, and consultation, the stakeholders could contribute to solving the Pandan Wangi rice agribusiness growth problem. The results of this research are useful, first, as a guideline tool for rice producers and stakeholder groups in preparing detailed action plans to implement the strategy using a participatory approach. Second, to determine the extent to which stakeholders could add value within the rice supply chain.

For further research, we encourage the implementation of stakeholders' participatory framework to be assessed further, to reveal the extent to which this framework could generate proven additional value and achieve business growth of rice agribusiness. In addition, we also suggest this model be assessed in relation to different agricultural products and market areas to increase the generalization of the framework implementation.

\section{Acknowledgements}

The authors would like to thank Azalia Shafira and Winda Andita for their contribution to this research.

\section{References}

African Development Bank (ADB). (2001). Handbook on stakeholder consultation and participation in ADB operations. Environment and Sustainable Development Unit 2001.

Alemu, D. \& Shiratori, K. (2011). Stakeholder analysis in rice research development, Assefa, K., Alemu, D., Shiratori, K., and Kirub, A. (Eds), Challenges and opportunities of rice in Ethiopian Agricultural Development (pp. 23-31). Ethiopian Institute of Agricultural Research.

Al-Hassan, R. M., Agbekpornu, H. G., \& Sarpong, D. B. (2008). Consumer Preferenc es for Rice Quality Characteristics in Accra. Agricultural and Food Science Journal of Ghana, 7.

Anang, B. T., Adjetey, S. N. A., \& Abiriwe, S. A. (2011). Consumer preferences for rice quality characteristics and the effects on price in the Tamale Metropolis, Northern Region, Ghana. 
Azabagaoglu, M. O., \& Gaytancioglu, O. (2009). Analyzing consumer preference to different rice varieties in Turkey. Agricultura Tropica Et Subtropica, 42(3), 118-125.

Bairagi, S., Mohanty, S., \& Custodio, M. C. (2019). Consumers' preferences for rice attributes in Cambodia: a choice modeling approach. Journal of Agribusiness in Developing and Emerging Economies. https://doi.org/10.1108/JADEE09-2017-0092

Brugha, R., \& Varvasovszky, Z. (2000). Stakeholder analysis: a review. Health policy and planning, 15(3), $239-246$. https://doi.org/10.1093/heapol/15.3.239

Bryson, J. M., Patton, M. Q., \& Bowman, R. A. (2011). Working with evaluation stakeholders: A rationale, stepwise approach and toolkit. Evaluation and program planning, 34(1), 1-12. https://doi.org/10.1016/j.evalprogplan.2010.07.001 Childs, N. (1993). Americans are eating more rice. Food Review/National Food Review, 16(1482-2017-3327), 19-25.

Cuevas, R. P., Pede, V. O., McKinley, J., Velarde, O., \& Demont, M. (2016). Rice grain quality and consumer preferences: a case study of two rural towns in the Philippines. PloS one, 11(3), e0150345. https://doi.org/10.1371/journal.pone.0150345

Fassin, Y. (2008). Imperfections and shortcomings of the stakeholder model's graphical representation. Journal of business ethics, 80(4), 879-888. https://doi.org/10.1007/s10551-007-9474-5

Freeman, R. E., \& McVea, J. (2001). A stakeholder approach to strategic management. The Blackwell handbook of strategic management, 189-207. DOI:10.1111/b.9780631218616. 2006.x

Flor, R. J., Maat, H., Hadi, B. A. R., Then, R., Kraus, E., \& Chhay, K. (2020). How do stakeholder interactions in Cambodian rice farming villages contribute to a pesticide lock-in?. Crop Protection, $135,104799$. https://doi.org/10.1016/j.cropro.2019.04.023

Golder, B., \& Gawler, M. (2005). Cross-cutting tool: Stakeholder analysis. Resources for Implementing the WWF Standards.

Grimble, R. (1998). Stakeholder methodologies in natural resource management.

Grimble, R., \& Chan, M. K. (1995, May). Stakeholder analysis for natural resource management in developing countries: some practical guidelines for making management more participatory and effective. In Natural resources forum (Vol. 19, No. 2, pp. 113-124). Oxford, UK: Blackwell Publishing Ltd. https://doi.org/10.1111/j.14778947.1995.tb00599.x

Indumathi, V. M., Mahendran, K., Lavanya, S. M., \& Hemalatha, S. (2017). Stakeholder Analysis in Paddy Processing Chain of Southern Tamil Nadu. Economic Affairs, 62(1), 55. DOI:10.5958/2230-7311.2017.00038.1

Isvilanonda, S., \& Kongrith, W. (2008). Thai household's rice consumption and its demand elasticity. ASEAN Economic Bulletin, 25(3), 271-282.

Jarvis, A. (2015). Identifying and prioritizing knowledge gaps in climate change adaptation in the Andes, International Centre for Tropical Agriculture (CIAT) (pp. 1-11). Bonn: UNEP-UNFCCC organised Adaptation Knowledge Day in SB42.

Jepsen, A. L., \& Eskerod, P. (2009). Stakeholder analysis in projects: Challenges in using current guidelines in the real world. International journal of project management, 27(4), 335-343. https://doi.org/10.1016/j.ijproman.2008.04.002

Kaiser, M., \& Forsberg, E. M. (2001). Assessing fisheries-using an ethical matrix in a participatory process. Journal of Agricultural and Environmental Ethics, 14(2), 191-200.

Karakosta, C., Flamos, A., \& Forouli, A. (2017). Identification of climate policy knowledge needs: A stakeholder's consultation approach. International Journal of Climate Change Strategies and Management, 10 (5), $772-795$. Karakosta, C., Flamos, A., \& Forouli, A. (2018). Identification of climate policy knowledge needs: a stakeholder's consultation approach. International Journal of Climate Change Strategies and Management. https://doi.org/10.1108/IJCCSM-05-2017-0117

Krywkow, J., \& Hare, M. (2008, July). Participatory process management. In 4th Biennial Meeting of International Congress on Environmental Modelling and Software, iEMSs 2008: Integrating Sciences and Information Technology for Environmental Assessment and Decision Making (pp. 888-899). International Environmental Modelling and Software Society (iEMSs).

Lagabrielle, E., Botta, A., Daré, W., David, D., Aubert, S., \& Fabricius, C. (2010). Modelling with stakeholders to integrate biodiversity into land-use planning-Lessons learned in Réunion Island (Western Indian Ocean). Environmental Modelling \& Software, 25(11), 1413-1427. https://doi.org/10.1016/j.envsoft.2010.01.011 
Laitinen, H., Saari, J., Kivistö, M., \& Rasa, P. L. (1998). Improving physical and psychosocial working conditions through a participatory ergonomic process A before-after study at an engineering workshop. International Journal of Industrial Ergonomics, 21(1), 35-45. https://doi.org/10.1016/S0169-8141(97)00023-1

Lançon, F., Erenstein, O., Akande, S.O., Titilola, S.O., Akpokodje, G. \& Ogundele, O.O. (2003). Imported rice retailing and purchasing in Nigeria: A survey. Bouaké, Côte d'Ivoire: West Africa Rice Development Association.

Nielsen AC (2010). SES (Socio-Economic Status) Indonesia. Retrieved from http://vidinur. net/2010/11/04/ses-socioeconomic-status-indonesia/

Ogundele, O. (2014). Factors influencing consumer's preference of local rice in Nigeria. African Journal of Marketing Management, 6 (4), 49-55.

Okry, F., Van Mele, P., Nuijten, E., Struik, P. C., \& Mongbo, R. L. (2011). Organizational analysis of the seed sector of rice in Guinea: stakeholders, perception and institutional linkages. Experimental Agriculture, 47(1), 137.

Pedrosa, T. \& Guimarães Pereira, Â. (2006). Participatory tools. Amsterdam: Institute for Environmental Studies, VU University of Amsterdam. Retrieved from www.ivm.vu.nl/en/Images/PT0_tcm53-161505.pdf

Reed, M. S., Graves, A., Dandy, N., Posthumus, H., Hubacek, K., Morris, J., ... \& Stringer, L. C. (2009). Who's in and why? A typology of stakeholder analysis methods for natural resource management. Journal of environmental management, 90(5), 1933-1949. https://doi.org/10.1016/j.jenvman.2009.01.001

Sakolwitayanon, H., Soni, P., \& Damien, J. (2018). Attributes determining consumer preference for organic rice in Bangkok, Thailand. British Food Journal. https://doi.org/10.1108/BFJ-12-2017-0667

Slocum-Bradley, N. (2003). Participatory Methods Toolkit: A Practitioner's Manual.

Spangenberg, J. H., Heong, K. L., Klotzbücher, A., Klotzbücher, T., Nguyen, Q. A., Tekken, V., ... \& Settele, J. (2018). Doing what with whom? Stakeholder analysis in a large transdisciplinary research project in South-East Asia. Paddy and Water Environment, 16(2), 321-337. https://doi.org/10.1504/IJSD.2013.053791

Suwannaporn, P., Linnemann, A., \& Chaveesuk, R. (2008). Consumer preference mapping for rice product concepts. British Food Journal.

Voicu, M.C. (2013). Characteristics of the consumer preferences research process. Global Economic Observer, 1 (1), 126-134.

Wang, J., \& Aenis, T. (2019). Stakeholder analysis in support of sustainable land management: Experiences from southwest China. Journal of environmental management, 243, 1-11. 